\title{
Farmers' Willingness to Pay for Private Irrigation Supply in Nandom District, Ghana
}

\author{
Yussif, $K$. \\ University for Development Studies, Nyankpala Campus, Ghana \\ kamaldeenyussif@ymail.com \\ Obeng, F.K. \\ University for Development Studies, Nyankpala Campus, Ghana \\ fkobeng@uds.edu.gh \\ and \\ Ansah, I.G. K. \\ University for Development Studies, Nyankpala Campus, Ghana \\ DOI//http://dx.doi.org/10.4314/gjds.v14i1.3
}

\begin{abstract}
This study investigated farmers willingness to pay (WTP) for private irrigation in Nandom district, Ghana. The study randomly sampled 236 farmers and analyzed data using descriptive statistics and ordered logit regression model. Results revealed that 94.5 percent of the farmers were WTP for private irrigation services with a mean of 35.83 cedis. Farmers' WTP is determined by income, age, farm size, engagement in an off-farm occupation, labour hours invested in farm operation, yield losses experienced from drought, anticipated yield gain from the use of irrigation, engagement in dry season gardening and access to extension services. It was concluded that the establishment of private irrigation schemes is a feasible venture and should be considered as a policy option for improved supply of agricultural water. To sustain farmers' WTP for private irrigation service, the creation of off-farm ventures is recommended as it serves as alternative income sources to finance farm operations.
\end{abstract}

Keywords: Farmers' Willingness to Pay, Private Irrigation, Ordered Logit Regression, Nandom

\section{Introduction}

Rain-fed agriculture is the main economic activity on which 80 percent of the district's economy is dependent (NDA, 2014). Drought, however, presents a serious threat to crop production in the northern Ghana. As a result, farmers in some districts of the north are saddled with in low crop output, low and unstable household income, worsened food insecurity and migration of their household members (Rademacher-Schulz \& 
Mahama, 2012). Nandom is one of such districts. To address this production challenge and to enhance the livelihoods of farmers in the dryer northern Ghana, agricultural planners have in the past developed state-sponsored irrigation facilities in the drier parts of Ghana to provide water for all year round farming. The development has created employment opportunities for farmers whiles also stabilizing food prices, thus, ensuring food security and poverty reduction.

However, lack of finance, inadequate access to complementary yield-enhancing inputs and technical constraints (poor planning and faulty design) has limited government's effort to supply irrigation despite the growth in its demand (Namara et al., 2011).

Ghana's current policy on agriculture water supply, the National Irrigation Policy, Strategies and Regulatory Measures 2011, seeks to increase private sector investment in the Ghanaian irrigation service (Namara et al., 2011). This is promoted with the understanding that private sector will inject the needed capital to expand existing irrigation schemes, develop new ones, build manpower, promote efficient management and bring full cost recovery to the sector (MoFA, 2011). This also calls for the need to examine farmers' demand for private irrigation service and private sector participation.

For the private sector players to make these investments, they need to be assured of realistic pricing mechanism that will yield positive returns on the investments. Such investment demands that farmers are willing to pay realistic prices because private service provision is a function of beneficiary's willingness to pay (WTP) for the full cost of the service delivered. Ascertaining the characteristics of farmers who are willing to pay for private irrigation is therefore crucial for targeting decisions of private irrigation suppliers.

These concerns relating to the provision of private irrigation in Ghana have not been studied although they must be addressed to inform policy. Earlier empirical works carried out in Ghana on water supply have concentrated on the benefits of irrigation to household food and leisure (Bagson \& Kuuder, 2013), willingness to pay for household water supply (Ayamga et al, 2008) and willingness to pay for improved irrigation services (Zakaria et al., 2014 and Baidoo et al., 2012). In the study area specifically, Bagson and Kuuder, (2013) examined how irrigation affects household food security and leisure. To deliver sustainable irrigation, however, there is the need to assess the potential for private supply based on farmers' WTP realistic prices for these services. The absence of empirical study on farmers' willingness to pay realistic tariffs for the provision of private irrigation leaves a gap in the implementation of Ghana's current policy and puts potential private irrigation suppliers in a dilemma as to whether to invest in the sector or not. To bridge this knowledge gap, this study empirically investigated the determinants of farmers' WTP for private irrigation services. 


\section{Literature Review}

\section{Willingness to Pay}

Willingness to pay (WTP) is the 'maximum amount that an individual states they are willing to pay for a good or service' (Department for International Development [DFID], 1997; Wedgwood and Sansom, 2003:5). It involves asking respondents about the maximum amount of money they will be willing to pay for a good or service using a series of structured questions (Altaf et al., 1992) so that the capacity of social groups to pay for a hypothetical monetary value of a programme or intervention can be estimated (Quevedo et al., 2009).

There are a number of methods for estimating WTP. Wedgewood and Sansom (2003) have indicated three ways of estimating WTP and these are: (1) observing the prices that people pay for goods in various markets (i.e. water vending, buying from neighbours, paying local taxes), (2) observing individual expenditures of money, time, labour, etc. to obtain goods or to avoid their loss and (3) asking people directly what they are willing to pay for goods or services in the future. They have categorised the first two (1 and 2) as revealed preference or indirect valuation methods because they are based on people's behaviour towards a good and the third (3) as stated preference or direct valuation methods because they are based on the value a consumer places on non-market good when asked directly about the good in a survey (Devicienti et al., 2004).

The revealed preference methods include market data approach, experiment (laboratory experiment, field experiment and auction), travel cost, hedonic estimation and preventive expenditure whiles the stated preference methods include conjoint, discrete choice analysis, expert judgments and customer survey methods. The Contingency Valuation Method (CVM) is a direct customer survey that is used to determine the monetary value of goods and services for which there is no real market price (Mitchell \& Carson, 1989). Each of these categories, however, has its own strengths and weaknesses. Whereas the revealed preference methods fail to capture non-use values of the resources and are thus inadequate for assessing new policy initiatives, stated preference methods afford the researcher the opportunity to estimates both use and non-use values and can be used to estimate values of proposed new policies (Young, 2005).

For this study the Contingent Valuation Method (CVM), was the preferred method because it is capable of estimating both use and non-use values (Carson, Flores \& Meade, 2001) of services like agricultural water supply. In its purest form, CVM is used to elicit consumers maximum WTP for selected service options (Wedgwood \& Sansom, 2003). It employs a hypothetical market condition which typically uses survey to inquire about potential consumers WTP for services. 


\section{Theories to Explain Individuals' WTP}

Several theories/models have been propounded to explain individual's WTP. These theories are the Basic Economic Model, the Theory of Public Goods, the AttitudeBehaviour Paradigm and Theory of Planned Behaviour, the Models of Altruistic/Moral Behaviour and the Norm-Activation Model. These theories explain individual's WTP from disposable income constrain to choices and responses (Basic Economic Model), the perspective of contributing to the provision of a public good (Theory of Public Goods Model), the assumption that behaviour can be predicted by attitudes and intentions to perform a behaviour (Attitude-Behaviour Paradigm and Theory of Planned Behaviour) and the assumption that individuals have perceived moral obligations to contribute to societal good (Models of Altruistic/Moral Behaviour and Norm-Activation Model).

The framework for this study was adapted from a modification of Basic Economic Model. The model is measured on two determinants of WTP; income and the use of the good in question. It posits that individual's choices and responses in paying for goods or services are constrained by their disposable income (Carson et al., 2001). Income and amount of money consumers are willing to pay for goods should therefore correlate. In line with this narrative, Donkoh et al. (2014) posit that for goods considered superior or normal goods, consumers are expected to purchase more as their incomes increase. Income is therefore expected to positively relate to WTP in WTP model.

The use of a good is another determinant closely related to economic value concept (Liebe et al, 2011) and has two dimension; the good being used by an individual and the individual's perception of its usefulness. People use the good because it is increasing their well-being and hence can attribute a direct link between the good and the individual's well-being as expressed by the concept of "use values". Conversely, users of goods or services are more likely to be willing to pay more than non-users (Carson et al., 2001). An individual who does not use the good in question, can express the usefulness of the good based on his/her knowledge about the good (Liebe et al., 2011). Consumers with positive views of the usefulness of a good are expected to be ready to pay more than their counterparts who think otherwise.

\section{Empirical Evidence of CVM Studies on Agricultural Water Supply Services}

CVM has been used extensively for the valuation of improved water supply for both household and agriculture, though its original usage was in valuing environmental benefits. Some relevant CVM studies on improved agricultural water supply are reviewed below. 
In Spain, Mesa-Jurado et al. (2011) employed the CVM to estimate economic value of guaranteed water supply for irrigation under scarcity conditions in Spain and realised that household income, household size and agricultural training had positive effect on WTP whiles age, olives per hectare and water dose had significant negative influence on WTP. Basarir et al. (2009) estimated producers' WTP for high quality irrigation water in Turkey using random sample of 130 producers from Turhal and Suluova regions and found out that male producer, producers from Turhal region, producers with more vegetable land, and producers with polluted water were willing to pay more for increasing the quality of irrigation water. Mallios and Latinopoulos (2001) measured farmers' willingness to pay for irrigation water in Greece and found out that age, annual water need, number of wells used and bid level negatively impacted WTP whiles income, experience of declining water supply, experienced impact of water scarcity, family size and education had positive effects on WTP.

In India, Chandrasekaran et al. (2009) analysed farmers' WTP for irrigation water under tank irrigation systems using a sample of 62 tank irrigators and the result revealed that nearly 50 percent of the farmers were willing to pay for irrigation water during the wet season and two-third were WTP in the dry season. Tang, Nan \& Liu (2013) estimated WTP for irrigation water using random sample of 600 rural households in northwest China and realised that the bid variable and family size were negatively related whiles income, irrigated area, major source of irrigation water and respondent's satisfaction of management were positively and significant related to WTP. In Kenya, Omondi et al. (2014) analysed factors affecting farmers' WTP for irrigation water and noticed that off-farm income, access to credit and satisfaction with the management of water supply system positively influenced farmers' WTP for irrigation water. Household size and land size had negative effect on WTP. Fakayode et al. (2010) examined a publicprivate partnering initiative for providing irrigation facilities to farmers under the Oshin Irrigation scheme in Kwara State, Nigeria. They identified age of farmers, type of education acquired by farmer, farmers' household income and size of farmers' household as determinants of farmers' ability to pay.

In Ghana, Zakaria et al., (2014) examined factors affecting farmers' WTP for improved irrigation services at the Botanga irrigation scheme and found a mean WTP price of GHS 22.92 (\$10.51) to be far below management proposed price of GH\$50.00 (US\$22.94)). They also found age, off-scheme income and maintenance culture of irrigation facilities, on-scheme income as ratio of household income as variables that influenced farmers' WTP. In the Upper East Region of Ghana, Baidoo et al., (2013) estimated farmers' WTP for improved access to water for irrigation using a sample of 282 household heads and the results showed that 79.5 percent of the farmers interviewed were willing to pay for improved system of irrigation whiles crop type, soil type and season were significant 
determinants of WTP for improved irrigation system. Again dry season farmers and farmers cultivating water-loving crops (tomatoes, melon, onions and garden eggs) were more willing to pay for improved system.

\section{Methodology}

\section{The Study Area}

The study was carried out in four communities (Kokoligu, Ketuo, Brutu \& Puffein) in the Nandom district of the Upper West Region of Ghana. The district is located in the North-Western corner of Ghana within Longitude $2^{\circ} 25 \mathrm{~W}$ and $2^{\circ} 45 \mathrm{~W}$ and Latitude $10^{\circ} 20$ and $11^{\circ} \mathrm{Oo}$ with a total area of 567.6 square $\mathrm{km}$. The district has a population of 56,090 , with 95per cent of the inhabitants in the rural areas (NDA, 2014). The main crops grown are guinea corn, millet, maize, cowpea and groundnut. The yields of these crops are very low because of the erratic rainfall pattern (NDA, 2014).

\section{Sample Selection Procedure}

A three stage sampling procedure was used to select 236 farmers from which primary data were collected. In the first stage, the district was purposively selected because of its great potential for irrigation development and the fact that small-scale informal irrigation to supplement production during the dry season abounds in the district although there are no installed irrigation facilities. Besides, the district experiences very frequent drought. In the second stage four communities, namely, Kokoligu, Ketuo, Brutu and Puffein were sampled because of the prevalence of dry season gardening, which was used as a pretext to farmers' readiness to use irrigation. The third stage involved a stratification of the farmers into dry season and non-dry season gardening farmers followed by a random selection of equal numbers (118) dry season and non-dry season gardeners bringing the total sample to 236 farmers. Preliminary community visits showed that there were about 170 farmers in the selected communities engaged in dry season gardening. Using the Krejcie and Morgan (1970) table for determining sample size 118 farmers engaged in dry season gardening selected. Equal number (118) of non-dry season gardeners were randomly selected thus giving a total sample of 236 farmers.

Data were collected using a Contingent Valuation (CV) questionnaire. The close-ended, double-bounded approach with an open-ended option to determine the maximum amount beyond which the farmer will not be willing to pay was employed. The CV methodology has been used to elicit consumers' WTP for almost all environmental services, including household water supply (Ayamga et al., 2008 and Farolfi, Mabugu \& Ntshingila, 2007), watershed services and conservation (Ndetewio, Mwakaje, Mujwahuzi \& Ngana, 2013), improved sanitation services (Whittington et al., 1993), agricultural 
services (Ulimwengu, John \& Sanyal, 2011) and irrigation services (Baidoo et al., 2013, Fakayode, Ogunlade, Ayinde \& Olabode, 2010, Mezgebo, Tessema \& Asfaw, 2013, Omondi, Mbogoh \& Munei, 2014) among others. The questionnaire was pre-tested using 10 respondents. Face-to-face interviews were used for the final survey.

\section{Method of Data Analysis}

Farmers who offered a zero price bid were considered protest bidders (Mitchel \& Carson, 1989). In line with the proposal of Kawagoe and Fukunaga, (2001), protest bidders were eliminated from further analysis.

\section{Analytical Framework}

This study adopted the framework of the Random Utility Model (RUM) as developed by Lancaster, (1966) and McFadden, (1974) and employed by Walker and Ben-Akiva, (2002). The model is based on the notion that the individual derives utility which is a function of a set of explanatory variables, by choosing an alternative (Walker \& Ben-Akiva, 2002). However, utility is also subjective as it depends not only on the good, but also on the individual, situation or time under which the individual is faced with the choice (Donkoh, Danso-Abbeam \& Yussif, 2014). The basic root for analyzing these contingent valuation responses is therefore grounded in this notion.

Based on this, the study denoted the existing water supply scheme to be $\mathrm{q}_{\mathrm{o}}$ and the proposed privative irrigation scheme to be $\mathrm{q}_{1}$. The utility functions associated with the existing water supply system and hypothetical private irrigation is written in the following form:

Existing Water Supply Scheme:

$$
U_{0}=v_{0}\left(q_{0}, I, F, S, P, e_{0}\right.
$$

Hypothetical private irrigation:

$$
U_{1}=v_{1}\left(q_{1}, I-M, F, S, P, e_{1}\right)
$$

$\boldsymbol{e}_{0}$ and $\boldsymbol{e}_{1}$ in equations 1 and 2 are error terms distributed normally with mean o and variance 1

I is the yearly average farmer income; $F$ is a vector of farm characteristics; $S$ is a vector of socioeconomic characteristics of the respondent and $\mathrm{P}$ is a vector of perception variables. ' $\mathrm{M}$ ' is the amount farmers are willing to pay for the hypothetical private irrigation. 
Farmers' decision to pay for private irrigation depends on the utility obtained from existing water supply and variation in income level for attaining the hypothetical source. Farmers will agree to pay for private irrigation if:

$$
v_{1}\left(q_{1}, I-M, F, S, P, e_{1}\right)>v_{0}\left(q_{0}, I, F, S, P, e_{0}\right)
$$

Thus, WTP for private irrigation will satisfy the following equality:

$$
v_{1}\left(q_{1}, I-M, F, S, P, e_{1}\right)=v_{0}\left(q_{0}, I, F, S, P, e_{0}\right)
$$

This procedure used to denote the existing and private water supply situation has been used by Omondi et al. (2014) in their study evaluating factors influencing farmers WTP for irrigation water in Kenya.

\section{The Ordered Logit Model}

The Ordered Logit Model (OLM) was deemed the most suitable model for analysis (Greene, 2003). The OLM enabled the study to investigate which characteristics raise the odds of accepting higher price ranges for private irrigation. From the random utility model, the ordered model with WTP as dependent variable was constructed as a function of independent variables including farm and farmer specific variables. The OLM is set up around a latent variable approach in the same manner as the binomial probit model which begins with:

$$
y^{*}=X^{\prime} \mathrm{b}+\mathrm{e}
$$

Where, $y^{*}$ is unobserved, and what can be observed is:

$$
y=\left\{\begin{array}{ccc}
0 & \text { if } & y \leq \mu_{1} \\
1 & \text { if } & \mu_{1} \leq y \leq \mu_{2} \\
2 & \text { if } & \mu_{2} \leq y \leq \mu_{3} \\
\vdots & \text { if } & \vdots \\
J & \text { if } & \mu_{J-1} \leq y
\end{array}\right\}
$$

Equation 2 is a form of censoring and the $\mu$ 's are unknown threshold parameters to be calculated with $\boldsymbol{\beta}$. It is presumed that $\varepsilon$ is normally distributed across observations. By normalizing the mean and variance of $\varepsilon$ to zero and one, the following probabilities are obtained: 


$$
\begin{gathered}
\operatorname{Pr} o b(y=0 / X)=F\left(-X^{\prime} \beta\right) \\
\operatorname{Pr} o b(y=1 / X)=F\left(\mu_{1}-X^{\prime} \beta\right)-F\left(-X^{\prime} \beta\right) \\
\operatorname{Pr} o b(y=2 / X)=F\left(\mu_{2}-X^{\prime} \beta\right)-F\left(\mu_{1}-X^{\prime} \beta\right) \\
\vdots \\
\operatorname{Pr} o b(y=J / X)=1-F\left(\mu_{J-1}-X^{\prime} \beta\right)
\end{gathered}
$$

Because all probabilities must be positive, the following condition should be established:

$0<\mu_{1}<\mu_{2}<\cdots<\mu_{J-1}$

In the ordered logit regression, the marginal effects of the covariates on the probabilities are not equal to the coefficients. Using a three category ordering, the marginal effects of changes in the covariates are obtained as follows:

$$
\begin{aligned}
& \frac{\partial \operatorname{Pr} o b(y=0 / X)}{\partial X}=-\phi\left(X^{\prime} \beta\right) \beta, \\
& \frac{\partial \operatorname{Pr} o b(y=1 / X)}{\partial X}=\left[\phi\left(-X^{\prime} \beta\right)-\phi\left(\mu-X^{\prime} \beta\right)\right] \beta, \\
& \frac{\partial \operatorname{Pr} o b(y=2 / X)}{\partial X}=\phi\left(\mu-X^{\prime} \beta\right) \beta .
\end{aligned}
$$

Marginal effects indicate how a change in an explanatory variable affects the predicted probability of consumers WTP for private irrigation.

\section{Empirical Model}

It was envisaged that farmers' WTP for private irrigation is influenced by age, sex, level of formal education, family size, farm size, annual average on-farm income, experience in farming, group membership, participation in dry season gardening, access to credit and extension, participation in an off-farm business venture, perceptions of yield loss due to drought, yield gain anticipated from irrigation use, and labour hours invested in farming. The variable specifications are illustrated in table 1.

The model chosen for estimating the relationship between WTP and the explanatory variables was specified as follows:

$$
\begin{aligned}
& W T P_{i}=\mathrm{b}_{0}+\mathrm{b}_{1} x_{1}+\mathrm{b}_{2} x_{2}+\mathrm{b}_{3} x_{3}+\mathrm{b}_{4} x_{4}+\mathrm{b}_{5} x_{5}+\mathrm{b}_{6} x_{6}+\mathrm{b}_{7} x_{7}+\mathrm{b}_{8} x_{8}+\mathrm{b}_{9} x_{9}+\mathrm{b}_{0} x_{0}+ \\
& \mathrm{b}_{1} x_{1}+\mathrm{b}_{2} x_{1}+\mathrm{b}_{3} x_{5}+\mathrm{b}_{4} x_{4}+\mathrm{b}_{5} x_{5}+\mathrm{b}_{6} x_{6}+\mathrm{b}_{7} x_{7}+\mathrm{b}_{8} x_{8}+\mathrm{e}_{i}
\end{aligned}
$$


Table 1: Measurement of independent variables and their a priori expectations

\begin{tabular}{|c|c|c|}
\hline Variable & Measurement of variable & $\begin{array}{l}\text { apriori } \\
\text { expectation }\end{array}$ \\
\hline Income $\left(\mathrm{X}_{1}\right)$ & Ghana Cedi (GH\$) & + \\
\hline Credit $\left(\mathrm{X}_{2}\right)$ & 1 if farmer has access to credit, o otherwise & + \\
\hline Age $\left(X_{3}\right)$ & Years & - \\
\hline $\operatorname{Sex}\left(\mathrm{X}_{4}\right)$ & 1 if farmer is a male, o otherwise & $-/+$ \\
\hline Education $\left(\mathrm{X}_{5}\right)$ & Years of formal education completed & + \\
\hline Household size (X6) & Number of people in same household & + \\
\hline Dependents $\left(\mathrm{X}_{7}\right)$ & Number of dependents in household & - \\
\hline Farm size (X8) & Farmland cultivated in acres & + \\
\hline Farming Experience (X9) & Number of years the farmer has been in farming & - \\
\hline Labour (X10) & Labour hours spent on farming per week & + \\
\hline Extension $\left(\mathrm{X}_{11}\right)$ & 1 if farmer has access to extension, o otherwise & + \\
\hline Dry-Season Gardening (X12) & 1 if farmer is a dry season gardener, o otherwise & + \\
\hline Yield Loss (X13) & Perceived percent yield loss due to drought & + \\
\hline Yield Gain (X14) & Anticipated percent yield gain from irrigation & + \\
\hline Off-farm Occupation (X15) & 1 if farmer has off-farm income venture, o otherwise & + \\
\hline Group membership (X16) & $\begin{array}{l}1 \text { if farmer belongs to a farmer-based organisation, o } \\
\text { otherwise }\end{array}$ & + \\
\hline Ease of payment $\left(\mathrm{X}_{17}\right)$ & $\begin{array}{l}1 \text { if farmer thinks it is easy to pay for irrigation, o } \\
\text { otherwise }\end{array}$ & + \\
\hline Feasibility of payment (X18) & $\begin{array}{l}1 \text { if farmer thinks it is feasible to pay for irrigation, o } \\
\text { otherwise }\end{array}$ & + \\
\hline
\end{tabular}

\section{Results and Discussion}

\section{Farmers' Characteristics}

Descriptive results show a dominant male population of 58.5 percent and a mean household size of 7 members with 3 dependants. The mean age of the sample is 43.5 years; young farmers constitute only 27.1percent with an average of 23.6 years of experience in farming. The average farmer has 3 years of formal education but as many as 48.3percent never had any formal education. On the average, a farmer cultivates 5.6 acres with about 51.7percent cultivating less than 5 acres. The mean income a farmer earns is GH\$959 per annum with 40.7percent earning less than $\mathrm{GH} \$ 500$. About 58percent 
of the farmers interviewed have off farm occupation; 54.7percent have access to credit, 48.3percent belong to FBOs and 59.7percent have contact with extension officers.

Table 2: Summary of descriptive independent variables

\begin{tabular}{|l|l|l|l|}
\hline Variable & $\begin{array}{l}\text { Mean } \\
\text { (Std Deviation) }\end{array}$ & Variable & $\begin{array}{l}\text { Mean } \\
\text { (Std Deviation) }\end{array}$ \\
\hline Gender* & $0.58(0.49)$ & Credit access* & $0.55(0.50)$ \\
\hline Age & $43.54(12.21)$ & Extension access* & $0.60(0.49)$ \\
\hline Education & $3.73(4.45)$ & Group membership* & $0.48(0.50)$ \\
\hline Household size & $7.32(2.452)$ & Labour & $40.08(14.591)$ \\
\hline Dependents & $3.41(1.889)$ & Dry season gardening* & $0.50(0.500)$ \\
\hline Farming Experience & $23.61(13.13)$ & Yield Loss & $14.59(6.243)$ \\
\hline Farm Size & $5.56(5.04)$ & Yield Gain & $9.44(6.016)$ \\
\hline On-farm Income & $959.30(1331.58)$ & Off-farm Occupation* & $0.59(0.493)$ \\
\hline
\end{tabular}

* dummy variable

Source: Field survey, 2015

\section{Farmers WTP for Private Irrigation Services}

Most respondents (94.5 percent) were willing to pay for private irrigation with a mean WTP of GH $\$ 35.60$ and a standard deviation of 43.19. Only 5.5 percent of the farmers surveyed expressed their unwillingness to pay and were considered protest bidders. This WTP outcome is better than all reports of WTP reviewed in Ghana ZZakaria et al., (2014), Baidoo et al., (2013)\}. Figure 1 is a column chart depicting the result of farmers' willingness to pay for private irrigation.

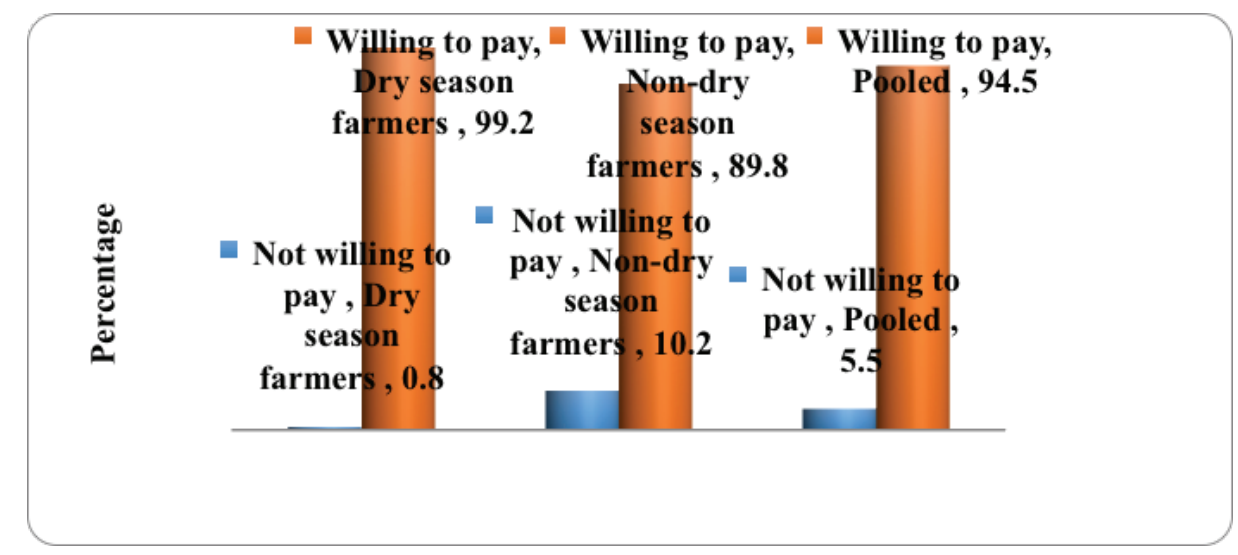

Figure 1: Farmers WTP for private irrigation

Source: Field Survey, 2015 
For the 5.5 percent who were not willing to pay, their main reasons were; "irrigation supply is government duty" (46.2 percent), "financial constraint" (30.8 percent), "unacceptable terms/condition of supply" (15.4 percent), and "high production expenditure" (7.7 percent). Majority of the 5.5 percent were non-dry season farmers who felt satisfied with water supply from rainfall.

Whereas 39.4 percent were willing to pay only at price range of GHđ (o $>x \leq 20$ ), 29.2 percent were willing to pay at price range of $\mathrm{GH} \Phi(20>\mathrm{x} \leq 40)$ and 25.9 percent were willing to pay at price higher than GH\$ 40 for private irrigation service (Table 2). It was also observed that as the bid price increased, the number of non-dry season farmers who were willing to pay decreased significantly relative to their dry season farming counterparts.

Table 3: Percentage of farmers willing to pay at different bid prices

\begin{tabular}{|l|l|l|l|l|l|l|}
\hline \multirow{2}{*}{ Bid price range } & \multicolumn{2}{|l|}{$\begin{array}{l}\text { Dry season } \\
\text { farmers }\end{array}$} & \multicolumn{2}{l|}{$\begin{array}{l}\text { Non-dry season } \\
\text { farmers }\end{array}$} & \multicolumn{2}{l|}{ Total } \\
\cline { 2 - 8 } & Freq & $\%$ & Freq & $\%$ & Freq & $\%$ \\
\hline Not willing to pay & 1 & 0.9 & 12 & 10.2 & 13 & 5.51 \\
\hline Willing to pay at GHథ $(\mathrm{o}>\mathrm{x} \leq 20)$ & 41 & 34.7 & 52 & 44.1 & 93 & 39.41 \\
\hline Willing to pay at GHథ $(20>\mathrm{x}<40)$ & 40 & 33.9 & 29 & 24.6 & 69 & 29.24 \\
\hline Willing to pay at GHథ $(\mathrm{x} \geq 40)$ & 36 & 30.5 & 25 & 21.2 & 61 & 25.85 \\
\hline Total & 118 & 100 & 118 & 100 & 236 & 100 \\
\hline
\end{tabular}

Source: Field survey, 2015

\section{Factors Influencing Farmers' WTP for Private Irrigation Services}

The study resolved practical problems that arise in the setting of regression analysis; missing observations, multicollinearity and outliers (Greene, 2003). The estimation result of the OLM is presented in table 4 below. The model produced a modest Pseudo R-squared of 0.3743 . Considering the fact that generally, discrete choice models produce low R-square, the model does a good job at fitting the data at hand. However, little emphasis is placed on the $\mathrm{R}^{2}$ since 'goodness of fit' is not too crucial compared to the statistical significance and economic importance of the explanatory variables (Wooldridge, 2010). The Likelihood Ratio (LR) test statistic of 137.9 indicates that the selected independent variables contributed to explaining WTP. 
Table 4: Ordered logit estimation results of farmers' WTP

\begin{tabular}{|l|l|l|}
\hline Variable & Coefficient $^{*}$ & Robust Std. Err. \\
\hline Farm size & $-.0277802^{*}$ & .0498287 \\
\hline Yield losses & $.1024681^{* *}$ & .0389175 \\
\hline Anticipated yield gain & $.1498798^{* * *}$ & .0367101 \\
\hline Dry Season & $.8092905^{*}$ & .3542851 \\
\hline Off-farm Occupation & $1.790089^{* * *}$ & .3875904 \\
\hline Farming experience & .0003318 & .0178149 \\
\hline Credit & -.0612901 & .348992 \\
\hline Age & $-.0441677^{*}$ & .0253165 \\
\hline Household size & .095299 & .0898304 \\
\hline Education & .0177813 & .0411784 \\
\hline Group membership & .2358604 & .3734153 \\
\hline Labour hours spent & $.0384553^{* *}$ & .014279 \\
\hline Extension access & $-.788768^{*}$ & .3676066 \\
\hline Dependents & -.1423338 & .1081199 \\
\hline Income & $.000481^{*}$ & .0002164 \\
\hline Sex & .1891059 & .3800635 \\
\hline
\end{tabular}

Number of observations $=223$ Log pseudo likelihood $=-151.01942$ Wald chi $^{2}(16)=137.90$, Prob $>$ chi ${ }^{2}=0.0000$, Pseudo $R^{2}=$ 0.3743

$\stackrel{* * * * * *}{*}$ indicate significance at $10 \%, 5 \%$ and $1 \%$ respectively

Source: Field survey, 2015

Out of 16 explanatory variables, 9 were statistically significant in relation to WTP. Sex, education, household size, number of dependants, farming experience, credit, and group membership variables were not significantly related to farmers' WTP.

In conformity with economic theory and a priori expectation, income had a positive sign. Thus higher income earners have higher propensities and are more willing to pay higher for private irrigation. If irrigation is assumed to be a normal good (which is reasonable), this follows basic economics of demand (Donkoh et al., 2014). Similar findings are reported in other studies on WTP for irrigation (Mallios \& Latinopoulos, 2001, Fakayode et al., 2010, Mesa-Jurado et al, 2011, Mezgebo et al., 2013, Ndetewio et al., 2013 and Tang et al., 2013). The implication is that as incomes of farmers' increase, they are more likely to pay higher prices for private irrigation. This relationship emphasizes the assertion that household WTP is a reflection of its ability to pay. 
Consistent with a priori expectation, off-farm employment had a significant positive relationship with WTP, implying that farmers who engage in off-farm ventures are more likely to pay higher prices for private irrigation supply. This is logical because if off-farm occupation generates income for farmers, it strengthens their purchasing power and hence ability to pay for irrigation. This finding confirms the result of Ndetewio et al. (2013), Omondi et al., (2014), and Zakaria et al., (2014) who found that the households that earned some off-farm income were more willing to pay for irrigation compared to their counterparts without off-farm occupation.

Labour also positively and significantly influenced WTP. Farmers who invest more time in their farming activities are more likely to pay higher for private irrigation services. This result is economically justified even though it contradicts the findings of Chandrasekaran et al (2009) who found labour usage to have a negative influence on WTP. Labour is required in practically all aspects of agricultural production; from planting to harvesting. Investing much time in these activities leaves the farmer with less time to engage in other economic ventures to support their livelihoods. Hence it will be more likely for farmers to pay higher prices to secure a venture they have invested much of their time in.

The results again indicate a positive and significant relationship between yield loss from drought and WTP. The implication is that farmers with higher yield losses due to drought are more likely to pay higher prices for private irrigation. This confirms the findings of Mallios and Latinopoulos (2001) that experience of declining water supply and impact of water scarcity had a positive effect on WTP. For this variable, the result can be a reflection of increasing water scarcity because droughts are negatively related to the water sufficiency. Farmers cultivating crops with higher water requirement are also more likely to opt for irrigation to avert drought and crop damage. The findings are in tandem with Chandrasekaran et al., (2009) who found crop exposure to drought to be related to farmers' WTP for irrigation. This defies income-demand relationship because even poor farmers facing greater crop damage from drought will welcome the idea of paying for private but secured irrigation supply.

Similarly, the significantly positive coefficient of anticipated crop yield gain from irrigation means farmers who expect more gains are more willing to pay higher price for private irrigation. This agrees with Basarir et al. (2009) who argued that greater expectation of more returns influences farmers' WTP. This is sound, since the primary interest of farmers is to obtain more output; hence, inputs that potentially generate more output will readily be accepted and paid for.

Farm size is positively related to WTP implying that farmers with large farm sizes are willing to pay higher prices for private irrigation. Owning larger farms moves the farmer 
into the realms of commercial agriculture. To minimize the risk of drought, such farmers will be more willing to pay for regular water supply under private irrigation than relying on rain-fed agriculture. Earlier studies whose findings are in line with the findings of this study include Ndetewio et al., (2013) and Mezgebo et al., (2013). However, other studies such as Chandrasekaran et al., (2009) and Omondi et al., (2014) contradict the relationship between farm size and WTP observed in this study. Using the economics of size principle (Boahene, 1995), a positive relationship between WTP and farm size is reasonable. This is because the large scale farmer stands to gain substantially from irrigation than their small land holding counterparts.

As expected, farmers who are into dry season gardening are more willing to pay higher prices for private irrigation services because they have firm knowledge of the value of dry season farming which uses water from irrigation supply to produce crops that generate income. In anticipation of more income from an irrigation scheme, they are more willing to pay for reliable water supply from private irrigation suppliers. Additionally, most dry season agriculture is based on production of water-loving crops. Farmers therefore have to pay for reliable water supply to secure their crops against drought, knowing that there may be no other alternative to growing these crops in the dry season. Usually, dry season farmers make more income from irrigated fields and should therefore be more willing to pay for irrigation from private suppliers. The result confirms the finding of Baidoo et al. (2013) that dry season farmers and farmers cultivating water-loving crops (tomatoes, melon, onions and garden eggs) are more willing to pay for water services.

Unlike the variables discussed above, extension access has a negative relationship with farmers' WTP, implying that farmers with extension access are willing to pay lower price for private irrigation. Relating extension contact to agricultural training, this finding contradicts that of Mesa-Jurado et al. (2011) who found a positive relationship between agricultural training and WTP for irrigation in Spain. Extension access and agricultural training are associated with more innovative behaviour, which is in turn related to adoption behaviour.

There is a negative relationship between the age of farmers and WTP. This means that younger farmers are more likely to pay higher prices for private irrigation. Younger farmers devote more resources (time, money, energy, labour) to their farming activities and would therefore not risk losing their investment because of water scarcity, hence, their likelihood of paying higher for private irrigation. This concurs with the findings of Mezgebo et al., (2013), Fakayode et al., (2010), and Mallios \& Latinopoulos, (2001).

To measure the instantaneous effect of a change in a particular explanatory variable on predicted WTP, keeping the effect of all other explanatory variables fixed, a marginal 
effect analysis was also conducted. The marginal effect of farm size was negative for the first class of WTP, that is for "WTP at GH $\mathrm{O}_{\mathrm{O}}>\mathrm{x} \leq \mathrm{GH} \Phi_{20} \mathrm{O}$ ", but it was positive for the next two classes i.e. $\mathrm{GH}_{2} \mathrm{O}>\mathrm{x}<\mathrm{GH} 4 \mathrm{O}$ and $\mathrm{x} \geq \mathrm{GH}_{4} \mathrm{O}$. The implications are that, as the farm size increases, the likelihood of paying between $\mathrm{GH}_{2} \mathrm{O}>\mathrm{x}<\mathrm{GH} \$_{4} \mathrm{O}$ and $\mathrm{x} \geq \mathrm{GH} \$ 4 \mathrm{O}$ ) also increases, while the likelihood of paying at the first bid GH $\mathrm{O}>\mathrm{x} \leq \mathrm{GH} \Phi_{2} \mathrm{O}$ declines. Thus, persons with large farm size are, in all likelihood, farmers who would pay a higher price for private irrigation services. The same interpretation can be expressed for income, yield loss, anticipated yield gain and labour hours spent variable, even though sizes of marginal effects varied.

The marginal effects of age on WTP at the first bid price, i.e. GH $\$$ o $>\mathrm{x} \leq \mathrm{GH} \Phi_{20}$ " is positive, but negative for the two other bid prices. This indicates that as farmers age increases, they would be willing to pay higher prices for irrigation at GHథ $\mathrm{O}>\mathrm{x} \leq \mathrm{GH} \Phi_{2} \mathrm{O}$ ". This, however, declines as the bid price increases to $\mathrm{GH} \$ 20>\mathrm{x}<\mathrm{GH} 440$ and $\mathrm{x} \geq \mathrm{GH} \$ 40$.

The marginal effects for dry season farming and off-farm occupation indicate that dry season farmers and farmers with off-farm occupation are more likely to be willing to pay higher, i.e. $\mathrm{GH} \$ 2 \mathrm{O}>\mathrm{x}<\mathrm{GH} \$ 4 \mathrm{O}$ and $\mathrm{x} \geq \mathrm{GH} \$ 40$ ), but are less likely to be willing to pay lower price, i.e. $\mathrm{GH} \$ \mathrm{O}>\mathrm{x} \leq \mathrm{GH} \$ 20$ ). 
Table 5: Estimated marginal effect after ordered logit

\begin{tabular}{|c|c|c|c|c|c|c|}
\hline \multirow[b]{2}{*}{ Variable } & \multicolumn{2}{|c|}{$\begin{array}{l}\operatorname{Bid} 1 \\
\operatorname{GH} \pitchfork(0>x \leq 20)\end{array}$} & \multicolumn{2}{|c|}{$\begin{array}{l}\operatorname{Bid} 2 \\
\mathrm{GH} \Phi(20>\mathrm{x} \leq 40)\end{array}$} & \multicolumn{2}{|c|}{$\begin{array}{l}\operatorname{Bid}_{3} \\
\mathrm{GH} \nsubseteq(\mathrm{x}>40)\end{array}$} \\
\hline & Coeff. & Std. Err. & Coeff. & Std. Err. & Coeff. & Std. Err. \\
\hline Farm size & $-.0277802^{*}$ & .01141 & $.0147368^{*}$ & .00715 & $.0130434^{*}$ & .00558 \\
\hline Yield losses & $-.0234457^{* *}$ & .00899 & $.0124374^{*}$ & .0058 & $.0110082^{*}$ & .00437 \\
\hline Anticipated yield gain & $-.0342939^{* * *}$ & .00852 & $.0181922^{* *}$ & .00644 & $.0161017^{* * *}$ & .00455 \\
\hline Dry Season ${ }^{\#}$ & $-.1843192^{*}$ & .08043 & $.0978434^{*}$ & .05163 & $.0864759^{*}$ & .03623 \\
\hline Off-farm Occupation" & $-.4038684^{* * *}$ & .08135 & $.2254204^{* *}$ & .06528 & $.178448^{* * *}$ & .04339 \\
\hline Farming experience & -.0000759 & .00408 & .0000403 & .00216 & .0000356 & .00192 \\
\hline Credit $^{\#}$ & .0140089 & .07959 & -.007407 & .04168 & -.0066019 & .03797 \\
\hline Age & $.010106^{*}$ & .00583 & -.005361 & .00326 & -.004745 & .00293 \\
\hline Household size & -.0218053 & .02062 & .0115673 & .01132 & .0102381 & .00977 \\
\hline Education & -.0040685 & .00942 & .0021583 & .00497 & .0019103 & .00449 \\
\hline Group membership $^{\#}$ & -.0538956 & .0856 & .0285058 & .04604 & .0253899 & .04027 \\
\hline Labour hours spent & $-.0087989^{* *}$ & .00327 & $.0046676^{*}$ & .00204 & $.0041313^{*}$ & .00169 \\
\hline Extension access ${ }^{\#}$ & $.1745502^{*}$ & .07895 & $-.0839052^{*}$ & .0423 & $-.090645^{*}$ & .04517 \\
\hline Dependents & .0325673 & .02476 & -.0172763 & .01412 & -.0152911 & .0115 \\
\hline Income & $-.0001101^{*}$ & .00005 & $.0000584^{*}$ & .00003 & $.0000517^{*}$ & .00002 \\
\hline $\operatorname{Sex}^{\#}$ & -.0434508 & .08773 & .0233768 & .04833 & .020074 & .03984 \\
\hline
\end{tabular}

${ }^{* * *},{ }^{* * *}$ indicate significance at $10 \%, 5 \%$ and $1 \%$ respectively

Source: Field survey, 2015

\section{Conclusion and Policy Implications}

The study has demonstrated that farmers are willing to pay for private irrigation services, especially those who are already engaged in dry season farming. With a mean WTP of GH\$35.6o per acre seasonally, the potential for private investors to set up private irrigation supply or for government to take advantage of public-private partnerships is bright. Our findings indicate that the mean WTP is higher than the recommended irrigation tariff ( $\mathrm{GH} \$_{50} / \mathrm{Ha}$ ) by Irrigation Company of Upper Region (ICOUR); the region's public sector irrigation service provider.

It is conclude that establishing private irrigation schemes in the district is a feasible venture and can be implemented to satisfy the agricultural water needs of farmers in the district. Since relatively young and wealthier farmers who engage in off-farm occupation are more likely to pay higher for private irrigation services, interventions 
in terms of irrigation provision should target such category of farmers. We recommend that the implementation should be done with the promotion of small and medium rural enterprises that improve off-farm incomes. This is because such alternative income sources enable farmers to finance farm operations, stabilize farm income and encourage long-term investment decisions for sustainable infrastructure like irrigation.

\section{References}

Altaf, M. A. Jamal, H. and Whittington, D. (1992). Willingness to pay for water in rural Punjab, Pakistan. UNDP - World Bank Water and Sanitation Program. International Bank for Reconstruction and Development/World Bank, Washington, DC USA.

Ayamga, M., Awuni J. A. and Jagri R. B. (2008). Willingness to pay for water in urban Ghana: the case of Tamale Metropolis. Ghana Journal of Development Studies 5(2) pp. 41-51.

Bagson E. and Kuuder, C. J. W. (2013). Assessment of a small scale irrigation scheme on household food security and leisure in Kokoligu; Ghana. Research on Humanities and Social Sciences 3(1), pp. 17-26.

Baidoo, I., Al-Hassan, R. M., Asuming-Brempong, S., Akoto, I. and Asante, F.A. (2013). Willingness to pay for improved water for farming in the Upper East Region of Ghana. Greener Journal of Agricultural Sciences 3(4), pp. 271-279, April 2013.

Basarir, A. Sayili, M. and Muhammad, S. (2009). Analysing producers' willingness to pay for high quality irrigation water. Bulgarian Journal of Agricultural Science 15, pp. 566-573.

Boahene, K. (1995). Innovation adoption as a socio-economic process; the case of the Ghanaian cocoa industry. Thesis Publishers, Amsterdam.

Carson, R. T. Flores, N. E. and Meade, N. F. (2001). Contingent Valuation: Controversies and Evidence. Environmental and Resource Economics 19 (2), pp. 173-210. Kluwer Academic Publishers. The Netherlands.

Chandrasekaran, K., Devarajulu, S. and Kuppannan, P. (2009). Farmers' willingness to pay for irrigation water: a case of tank irrigation systems in south India. Water 1(1). pp. 5-18.

Department for International Development [DFID], (1998). Draft Guidance Notes for DFID Economists on demand assessment in the water and sanitation sector, DFID, London

Devicienti, Klytchnikova, and Paternostro, (2004). Willingness to Pay for Water and Energy: an Introductory Guide to Contingent Valuation and Coping Cost Techniques. Energy Working Notes, No. 3, World Bank. 
Donkoh, S. A., Danso-Abbeam, G. and Yussif, K. (2014). Introductory economics. Fontstyle, Imprints, Ghana.

Fakayode, S. B. Ogunlade, I. Ayinde, O. and Olabode, P. (2010). Factors affecting farmers' ability to pay for irrigation facilities in Nigeria: The case of Oshin Irrigation Scheme in Kwara State. Journal of Sustainable Development in Africa 12(1), pp 334-349.

Farolfi, M. and Ntshingila (2007). Domestic Water use and values in Swaziland: A contingent valuation analysis. Agrekon 46(1), pp. 157-170.

Greene, W. H. (2003). Econometric analysis ( $5^{\text {th }}$ Ed.). Pearson Education, Inc., Upper Saddle River, New Jersey.

Gujarati, D. N. (2006) Essentials of econometrics. (3 ${ }^{\text {rd }}$ Ed.). McGraw-Hill, Irwin.

Gujarati, D. N. (2004). Basic econometrics, (4 ${ }^{\text {th }}$ Ed.). The McGraw-Hill Companies

Katchova, A. (2013a). Ordered probit and logit models. Econometrics academy. Retrieved from sites.google.com/site/econometricsacademy

Kawagoe, K. and Fukunaga, N. (2001). Identifying the value of public services by the contingent valuation method (CVM). Nomura Research Institute (NRI) Papers 39, Nomura Research Institute.

Krejcie, R. V. and Morgan, D. W. (1970). Determining sample size for research activities. Educational and Psychological Measurement 1 (30), pp. 607-610.

Lancaster, K. (1966). A new approach to consumer theory. Journal of Political Economy 74, No.2, pp. 132-157.

Liebe, U. Preisendörfer, P. and Meyerhoff, J. (2011). To Pay or Not to Pay: Competing Theories to Explain Individuals' Willingness to Pay for Public Environmental Goods. Environment and Behaviour 43(1): pp. 106-130. Sage Publications.

Lipton, M., Litchfield, J., Blackman, R., De Zoysa, D., Qureshy, L.and Waddington, H. (2003). Preliminary review of the impact of irrigation on poverty, with special emphasis on Asia. FAO, Rome, 2003. Retrieved from www.fao.org on January 10, 2016.

Long, J.S. (1997). Regression models for categorical and limited dependent variables. Advanced quantitative techniques in the social sciences. Sage publications Thousand Oaks, London and New Delhi.

Maddala, G. S. (1992). Introduction to econometrics ( $2^{\text {nd }}$ Ed.). Macmillan Publishing Company, United States of America. 
Mallios, Z. and Latinopoulos, P. (2001). Willingness to pay for irrigation water: a case study in Chalkidiki, Greece. 7 th International conference on environmental science and technology. Ermoupolis, Syros island, Greece - Sept. 2001.

McFadden, D. (1974). Conditional logit analysis of qualitative choice behavior. In: Zarembka, P. (Ed.), Frontiers of econometrics. pp. 105-142. Academic Press. New York

Mesa-Jurado, M.A, Martin-Ortega, J., Ruto, E. and Berbel, J. (002011). The economic value of guaranteed water supply for irrigation under scarcity conditions. Presented at the EAAE 2011 congress. Change and uncertainty challenges for agriculture, food and natural resources. August 30 to September 2, 2011 ETH Zurich, Zurich, Switzerland.

Mezgebo, A., Tessema, W. and Asfaw, Z. (2013). Economic values of irrigation water in Wondo Genet District, Ethiopia: An application of contingent valuation method. Journal of Economics and Sustainable Development 4(2), pp. 23-37.

Mitchell, R. C. and Carson, R. T. (1989). Using surveys to value public goods: The contingent valuation method. Washington, D.C.: Resources for the future.

Ministry of Food and Agriculture (MOFA) (2011). National irrigation policy, strategies and regulatory measures. Lamptey, Daniel, Nyamdi, Ben and Minta, Asare (eds). Ghana Irrigation Development Authority.

Namara, R. E., Horowitz, L., Nyamadi, B. and Barry, B. (2011). Irrigation development in Ghana: Past experiences, emerging opportunities, and future directions. GSSP Working Paper \#27, International Food Policy Research Institute, Washington D.C.

NDA, (2014). The composite budget of the Nandom District Assembly for the 2014 fiscal year. Retrieved from www.mofep.gov.gh

Ndetewio, P. I., Mwakaje, A. G., Mujwahuzi, M. and Ngana, J. (2013). Factors influencing willingness to pay for watershed services in lower Moshi, Pangani Basin, Tanzania. International Journal of Agriculture and Environment, 2, pp. 57-75.

Omondi, S. O., Mbogoh, S. G. and Munei, K. (2014). An evaluation of the factors influencing farmers' willingness to pay (WTP) for irrigation water: The case of Ahero Irrigation Scheme in Kenya. International Journal of Science, Environment and Technology 3(5), pp. 1778 - 1789.

Quevedo, J. F M. Hernández, I. C. Espinosa, J. G. and Escudero, G. S. (2009). The willingness-to-pay concept in question: A Review. Rev Saúde Pública, 43(2).

Rademacher-Schulz, C. and Mahama, E. S. (2012). "Where the rain falls" project. Case study: Ghana. Results from Nadowli District, Upper West Region. Report No. 3, Bonn, United Nations University-Institute for Environment and Human Security (UNU-EHS). 
Tang, Z., Nan, Z. and Liu, J. (2013). The willingness to pay for irrigation water: A case study in Northwest China. Global NEST Journal 15(1), pp. 76-84.

Ulimwengu, J. and Sanyal, P. (2011). Joint estimation of farmers' stated willingness to pay for agricultural services. IFPRI discussion paper 01070.

Walker, J. and Ben-Akiva, M. (2002). Generalised random utility model. Mathematical social sciences 43(3), pp. 303-343. ELSEVIER www.elsevier.com/locate/econbase

Wedgwood A. and Sansom, K. (2003). Willingness-to-pay surveys - A streamlined approach. Guidance notes for small town water services. Water, Engineering and Development Centre, Loughborough University, 2003.

Wooldridge, J. F. (2010). Econometric analysis of cross section and panel data. Cambridge, Massachusetts: MIT Press.

Young R.A. (2005). Determining the economic value of water: concepts and methods, resource for the future. Washington, DC.

Zakaria, H., Abujaja, A. M., Adam, H., Nabila, A. Y. and Mohammed, I. (2014). Factors affecting farmers willingness to pay for improved irrigation service: A case study of Bontanga Irrigation Scheme in Northern Ghana. International Journal of Agricultural Economics and Extension 2(1), pp. 068-076. 